\title{
The Politics of Human Perfection and the Politics of Human
}

\section{Imperfection: Chantal Mouffe versus Ulrich Beck and Anthony Giddens on European Inequalities}

\author{
Małgorzata Borkowska-Nowak \\ The John Paul II University of Lublin, Lublin, Poland
}

\begin{abstract}
The title of this paper refers to Michael Oakeshott's distinction between the politics of faith and the politics of scepticism. The "faith" expresses a belief in the capacity of government to concentrate all the power and resources upon the project of human improvement and perfection, while the "scepticism" is the politics of the powerless in which government cannot produce perfection and enjoys only limited opportunity of directing the activities of its subjects. The aim of this article is to revise Oakeshott's distinction in order to apply it to the discussion on inequalities affecting Europe. This discussion held by Chantal Mouffe, Ulrich Beck and Anthony Giddens focused on issues such as: modern patterns of inequality, the coexistence of different ethnic, religious and political forms of life, "legitimization" of social inequalities, the institutionalization of norms of equality, the problem of recognition, the common identity and so on. The key question is: How the values of equality and justice are best realized in the structure of modern society? To answer this question, it is necessary not only to assess critilically the authority of governments, but also to examine possible ways of development of the idea of liberal democracy and power relations in contemporary political sociétés. What is our perspective on the way to solve these problems-the reinvention of politics or democratizing democracy? Even if this research will not help us to find the best political project, however we may be less often cheated in this discussion by irrelevant and ambiguous arguments.
\end{abstract}

Keywords: human perfection, human imperfection, inequalities, liberal democracy, globalization

\section{Introduction}

The title of this paper refers to Michael Oakeshott's (1996) distinction between the politics of faith and the politics of scepticism (pp. 21-44). The "faith" expresses a belief in the capacity of government to concentrate all the power and resources upon the project of human improvement and perfection, while the "scepticism" is the politics of the powerless, the style of politics in which government cannot produce perfection and enjoys only limited opportunity of directing the activities of its subjects.

On the one hand, the "faith" represented by such thinkers as Rousseau and Marx, is opposite of traditional religious faith, however it stimulates the hope of salvation through politics and the promise of prosperity, affluence and welfare. There is nothing in the world of politics which does not spring from human effort, more

Małgorzata Borkowska-Nowak, Ph.D., Department of Philosophy, The John Paul II University of Lublin. 
strictly-from governments' activity and power to cope with their task. The politics of faith corresponds to a modern disposition which Oakeshott (1996) otherwise called "rationalism in politics" or the "ideological style of politics" (pp. X-XI, 45). In this sense, the politics of faith appears as the politics of human perfection, expressing our belief in a better world and a better man in it.

On the other hand, the "scepticism", exemplified by Pascal, Montaigne and Hume, is never omnipotent or absolute. It finds human existence to be so heterogeneous and complex that no plan to improve human beings, or the conduct of human beings, or even in a broad way human circumstances could ever succed. As Oakeshott (1996) explains, what is to be improved is the existing system of rights, duties and means of redress (p. 34). So, "improvement" here is merely part of the articulation of maintaining order. Looking from this point of view we can describe "scepticism" as the politics of imperfection, an expression of human precaution, doubts and weakness.

The politics of faith or human perfection and the politics of scepticism or human imperfection are not alternative styles of politics, but they are ideal as the abstract extremes. They define two manners of conducting and understanding the political, power and government, thereby specifying two poles between which modern European politics moves and has fluctuated for near five hundred years (Oakeshott, 1996, p. 21).

The aim of this article is to think over Oakeshott's apt distinction and reconsider to what extent we can apply it to the discussion on inequalities affecting Europe. It does not follow that the politics of faith and the politics of scepticism can be directly referred to Mouffe's, Giddens' and Beck's approaches. However, it seems that such a dychotomy opens new paths for reflection. It can serve as a source of ideas useful in order to define the theoretical framework of presented theories, showing at the same time that the problem of inequality is only a narrow aspect of broader debate on the political, democracy, government and power relations. For this reason this article will not focus on finding the effective ways of solving the problem of inequality, but rather on the theoretical level, more strictly on the implications of presented models of democracy for understanding global inequality.

The catalyst for this debate is Chantal Mouffe's analysis of liberal democracy with its weaknesses and pitfalls. Mouffe, one of the leading figures of post-Marxist political theorists, presents an extensive criticism of the current rationalist and individualist liberal approach, more strictly, the so-called "post-political" Zeitgeist, including theories announcing the twilight of politics and the political. As she explains, her target is those, in the progressive camp who accept this optimistic view of globalization and have become the advocates of a consensual form of democracy [...] Their aim is the establishment of a world "beyond left and right", "beyond hegemony", "beyond sovereignty" and "beyond antagonism" (Mouffe, 2005, pp. 1-2).

Mouffe has in mind two approaches toward liberal democracies: the deliberative model of democracy, represented by John Rawls and Jürgen Habermas, as well as the theory of "reflexive modernity", exemplified by sociologists such as Ulrich Beck and Anthony Giddens. The core of Rawls' and Habermas' approaches is a belief in the perfectly reconciled world with the political as a space of freedom, equality and public deliberation. Rawls (1998) points out that unresolved conflicts are a thing of the past and consensus can now be obtained through dialogue (pp. 194-243). At the same time Giddens and Beck convince that politics can no longer be devided along traditional lines, such as left/right, public/private or radical/conservative and that the "free world" without enemies ("partisan-free democracy", "cosmopolitan democracy") is now possible (Giddens, Beck, \& Lash, 2009, pp. 37-38). 
Mouffe exposes weaknesses of those approaches and shows their limitations on the way of solving problems relating to economic globalisation and inequalities. Her discussion with Giddens and Beck includes questions such as: How are we going to address the profound inequalities which exist in the world? What should governments do? And after all: how the values of equality and justice are best realized in the basic structure of society? To answer these questions it is necessary not only to assess critlically the authority of governments, but also to examine possible ways of development of the idea of liberal democracy and power relations in contemporary political societes. What is our perspective - the reinvention of politics or democratizing democracy? A significant part of my argument will consist in examining the main tenets of this discussion. Even if it will not help us to find the best political project and distinguish between good and bad politics, however we may be less often cheated in this discussion by irrelevant and ambiguous arguments.

\section{Anthony Giddens and the Third Way}

The key concept of Anthony Giddens' political philosophy is "manufactured uncertainty". It characterizes both the lifestyle and activities of post-traditional societies. Giddens argues that modernity has become experimental and variable in the sense that we are caught up in everyday experiments which involve a multiplicity of changes and have profound consequences for the self and identity (Mouffe, 2005, p. 42). This claim is close to the position of Zygmunt Bauman (2008), who points out that this kind of uncertainty, misgivings and fears about the future accompanied people in a fluid, ever-changing social environment, where the rules of the game are changed without warning and reason (p. 67).

Giddens stresses that the growth of manufactured uncertainty reveals the need for "social reflexivit" (because people have to process a lot of information to act in their daily life), "active trust" (because the propositions of experts are opened to critique by the citizens and passive trust is not enough) and security in an uncertain world. From this point of view we can qualify Giddens' project as the politics of scepticism and human imperfection. The world is profoundly imperfect and we can not really change it for the better. But, we should improve it, although government becomes increasingly redundant and human actions are always fragile, unstable and temporary. This is the argument for "democratization democracy".

Giddens argues that "democratization democracy" without defining the enemy is possible by the development of so-called "pure relationship" - a relationship into which one enters for its own sake because of the satisfaction that associating with others brings. In the area of personal life this type of "pure relationship" contribute to the development of "emotional democracy" as the model of "dialogic approach". In the public sphere "pure relationship" are the basis for the construction of "dialogic democracy". Its expression is the "life politics" which — according to Giddens-is not only a politics of the personal, but in general—relates to the challenges facing humanity and concerning life decisions about how we should live in a post-traditional world where what used to be natural or traditional has now become opened to choice (Dybel \& Wróbel, 2008, pp. 126-127; Mouffe, 2005, pp. 43-47). As Giddens (1991) explains: "Life politics concerns political issues which flow from processes of self-actualization in post-traditional contexts, where globalizing tendencies intrude deeply into the reflexive project of the self, and conversely where processes of self-realization influence global strategies" (p. 214). 
Globalization is a phenomenon that is happening here and is associated with all aspects of our lives (Beck, Giddens \& Lash, 2009, p. 129). As Giddens (1994) explains, Pressures towards democratization — which always face contrary influences - are created by the twin processes of globalization and institutional reflexivity. Detraditionalization disembeds local context of action and at the same time alters the character of the global order: even when they remain firmly adhered to, traditions are incrisingly forced into contact with one another. Globalization, reflexivity and detraditionalization creates "dialogic spaces" that must in some way be filled (pp. 130-131).

For this reason the problems of post-traditional world should be understood in the context of the complex effects of global strategies. Although globalization is hardly ever presented in a favourable light, Giddens sees it as opening many positive possibilities, especially to reduce global poverty and inequality. For him the main problems of underdevelopment don't lie in the global economy itself, or in the self-seeking behaviour of the richer nations but mainly in the societies themselves: in authoritarian government, corruption, conflict and the low level of emancipation of women (Giddens, 2000, p. 129). Giddens' essential argument is that global integration through trade and investment liberalisation will encourage competition and efficiency, which in turn will lead to economic growth, poverty reduction and narrowing of income inequalities between countries (Kiely, 2005, p. 136). This contention, similar to those made by International Monetary Fund and World Bank, is often criticized by scholars and activists, who argue that there is no a clear connection between economic growth and poverty reduction.

A positive response to globalization characterizes the Third Way as a new strategy for socialism, providing a "middle ground" between socialist values and neo-liberalism or market fundamentalism. Giddens, the leading advocate for the Third Way, believes that globalization brings benefits in the double sense. On the one hand it does push us towards decentralization and devolution of power, as well as towards the emergence of transnational forms of governance. On the other hand, globalization can support the modernizing left's attitudes towards the welfare state (Giddens, 1999, pp. 25-26). Giddens places the problem of inequality in this context and calls for a reduction of inequality of outcome.

He stresses that welfare systems protecting citizens from cradle to grave have often been bureaucratic and inefficient, therefore they have often failed the poor and the needy. The Third Way programme involves a radical reform of the welfare state, but it doesn't want to reduce the state to the role of night watchman. As Giddens (1999) points out,

A modernised welfare state would be one that is both internally reformed and brought into line with the demands of the global marketplace. It would, among other things, emphasise education, employability, the dissolution of poverty traps and the creation of pensions systems that take account of increased worker mobility and the decline of traditional corporate employment. (p. 26)

This is not to say that we should abandon the classic concern for social justice and the battle against inequality. However, according to Giddens, in order to solve the problem of inequality we need to remember two things. Firstly, that social justice involves reducing inequality of outcome. Secondly, that existing welfare systems have not been effective in redistributing income and wealth between rich and poor, so we have to look for a different solution. Giddens looks for a such redistributional programme which is compatible with individual initiative and freedom. For him, "It is an essential component of the global dialogue now under way" (Giddens, 1999, p. 26). 


\section{Ulrich Beck's Cosmopolitanism}

Ulrich Beck agrees with Giddens that politics can no longer be devided along traditional lines of left/right or public/private and that the growth of individualism made collective identities hopelessly outdated (Mouffe, 2005, p. 35). However, Beck goes considerably further than Giddens. He points out that with the collapse of the old world and the expiration of hostility between East and West, politics has spread outside the formal structures of responsibility and hierarchies. Contemporary politics is no longer identified with the state, political system, formal duties and politicians working full-time. The conviction that the "center governs" has been weakened, thereby revealing our need for a new form of politics. Beck calls it "sub-politics" and defines as a developing society from below. Sub-politics breaks the monopoly on the truth and disseminates the attitude of doubt, which is the political program of overcoming conflicts by excluding the possibility of the emergence of antagonistic relations. More specifically, in a society where uncertainty has become commonplace is no room for thinking in terms of friend and enemy, which necessarily leads to pacify conflicts (Beck, Giddens \& Lash, 2009, pp. 33, 40).

Beck argues that we are living now in a "reflexive modernity", which is a second stage of modernity. As he explains,

While simple modernization ultimately situates the motor of social change in categories of instrumental rationality (reflection), "reflexive" modernization conceptualizes the motive power of social change in categories of the side-effects (reflexivity). Things at first unseen and unreflected, but externalized, add up to structural rupture that separates industrial from "new modernities" in the present and the future. (Beck, 1997, p. 38)

This transition from one social epoch to another is not the upshot of political struggles, but the effect of those side effects (unexpected and unplanned), which are at the origin of the profound changes within social relations, concerning class, work, family relations, gender, and so on. As a consequence, the basic problems in a risk society are no longer distributive nature, about income, welfare benefit or job, but about "distributive responsibility" on ways to prevent and control the risks accompanying the production of goods and the threats caused by the progress of modernization (Mouffe, 2005, p. 37).

Futhermore, the issue of socio-economic distribution has been displaced by the issue of cultural domination: Unjustice is no longer understood in terms of economy, but rather in terms of culture, and in this dimension becomes the crucial problem of political conflicts. Shortly, the politics of recognition prevails nowadays the politics of redistribution. Consequently, the old continent can survive in competition with the young powers only if Europeans will be able to overcome old differences between us and others, between Europeans and non-Europeans. From this point of view, cosmopolitan opening seems to be both an opportunity and a necessity (Beck \& Grande, 2009, p. 276).

In this broad context, Beck developes his "cosmopolitan approach" on relations of social inequality. He elucidates it in three cases: the inequality of global risks; the Europe-wide dynamic of inequality; and transnational inequalities. Central to his argument is to highlight that individualization and the transnationalization of social inequalities bursts the framework of institutional responses: nation state, trade unions, welfare state systems and the national sociologies of social classes (Beck, 2007, p. 680).

At the starting point Beck argues that the nation state principle is no longer in a position to adequately describe inequalities and suggests to replace it with a more cosmopolitan vision, characterized by the side-effects 
principle (Martell, 2016). Many of the problems, such as ecological degradation (which leads to armed conflicts over resources), migration and the development of weapons of mass dectruction, require global solutions. Nation-states are not adequate for taking up such problems, so we need a system of global governance called cosmopolitan democracy (Martell, 2008, p. 129). This approach has at least two advantages. First, it reveals the connection between inequalities and global risks. Secondly, it allows us to better understand the relationship between national and global recognition of the issue of inequality.

Firstly, social inequality is closely linked with risk. There is a radical asymmetry between decision-makers who define the risk, take decisions and profit from them, and those who are assigned to them, who have to suffer the "unforeseen side effects" of the decisions of others, without having had the chance to be involved in the decision-making process (Beck, 2007, p. 692). Owing to the relationship between risk and power, danger could be exported from one country to another, usually to largely unresisting "side-effects countries"- low safety, low wage and low rights countries. Beck explains that the risks are "deported" to the region where they are not appreciated or not taken seriously. But it should be noted that the acceptance of dangers it is not the same as agreement, "dangers are not accepted, they are imposed. And it goes unnoticed, thanks to the power to present processes as if nothing of importance is happening" (Beck, 2007, p. 692). As a result, poverty and the accumulation of dangers are two sides of the same coin.

Secondly, from the cosmopolitan perspective, national borders institutionalize the incomparability of national spaces and in this way legitimize transnational and global inequalities. As Beck (2007) explains, "national standards of equality exclude transnational inequalities; intra-national comparability of inequalities ensures international incomparability" (p. 692). The point is that cosmopolitanism clarifies how the nation-state principle legitimates global inequalities. According to Beck, the national outlook legitimates global inequalities negatively by concealment, and positively by justifying them. There arises a number of questions here. For reasons of space I will limit my considerations to the most important remarks.

Beck, on the one hand, claims that metodological nationalism - too much "introverted", not oriented to external relations - justifies internal inequalities by the performance principle. On the other hand, Luke Martell believes that the opposite is true. As he explains, comparative sociology, as well as dependency theory and world systems theory have been important schools of thought in sociology which have shown inequality globally. It follows that methodological nationalism is not necessarily an introverted legitimation for inequality and can be compatible with global understanding of it (Martell, 2008). From this point of view Beck's viewpoint seems problematic.

We can put aside the discussion on the metodological nationalism to focus on Back's alternative. Regardless of how many issues should be discussed in this context, it is worth noting that for Beck problems relating to the environment, crime, human rights, terrorism, war, wealth, are global and require global responses. Global inequality and poverty are the most difficult issues. Democracy is established at national levels but important decisions have to be made globally, exceeding the national mechanisms of democracy (Martell, 2008, p. 130). If cosmopolitanism will be complemented with the principle of solidarity, postulated by Beck, there appears the chance for a dialogue over boundaries of nation-states. 


\section{Chantal Mouffe and a Radical Alternative}

Chantal Mouffe, unlike Back and Giddens, argues "that envisiging the aim of democratic politics in terms of consensus and reconciliation is not only conceptually mistaken, it is also fraught with political dangers" and "instead of contributing to a 'democratizing democracy', it is at the origin of many of the problems that democratic institutions are currently facing" (Mouffe, 2005, p. 2). Just to mention those relating to the coexistence of different ethnic, religious and political forms of life, "legitimization" of social inequalities, the institutionalization of norms of equality, the problem of recognition, the common identity and so on. These all are the symptoms of what Jacques Rancière (1991) calls a "postdemocracy", far from promoting a progress in democracy (p. 102).

To take up the challenges of the modern world, as Mouffe claims, it is necessary to understand that the political has to do with conflict and antagonism, so it is the realm of decision, not free deliberation. Properly political questions always require us to think politically, which always involves making decisions between conflicting alternatives. Unlike liberal thought, characterized by a rationalist and individualist approach, Mouffe points out that antagonism is not a mere empirical but a constitutive and ineradicable dimension in social life. There are conflicts for which no rational solution could ever exist. It implies a governing power, which is sufficient, or may become sufficient to establish an order (Mouffe, 2005, pp. 10-12). It is just this optimism expressing belief in the power of political solutions is the most important premise, based on which I define Mouffe's approach as the politics of human perfection.

Giddens and Beck are convinced that the "forces of progress" will prevail and a cosmopolitan order will be established, but Mouffe wonders, how we will get there and what will happen in a meantime. According to her, Giddens and Beck do not have good ideas of solving the issue of inequalities because they underestimate power relations and the way in which power relations build our societies. None of them do not realize how deeply the problems of "reflexive modernity" are related to neo-liberal policies with their emphasis on profit and market mechanisms. However, as Mouffe (2005) argues,

In all the crucial areas where power structures are at stake, their non-conflictual political approach is unable to pose the adequate questions [...] Without grasping the structure of the current hegemonic order and the type of power relations through which it is constituted, no real democratization can ever get off the ground. Whatever its proponents might claim, the "dialogical" approach is far from being radical because no radical politics can exist without challenging existing power relations and this requires defining an adversary, which is precisely what such a perspective forecloses. (p. 51)

I put this long quotation because it perfectly reveals the essence of Mouffe's approach. She agrees with Giddens and Beck that democratic politics cannot take the form of an implacable confrontation without undermining the principle of pluralism and, consequently, without leading to the destruction of the political association. At the same time she claims that the fundamental question for democratic theory is: Whether to support or challenge the consensual approach, but how the antagonistic dimension, constitutive of the political, can be given a form of expression that will not destroy the political association (Mouffe, 2005, p. 52).

Mouffe suggests that to answer this question it is necessary to reconcile, as far as possible, the universalistic and apolitical logic of liberalism with the antagonistic logic of democracy. Using her vocabulary: to develop truly political liberalism through recognition of the conflictual and antagonistic nature of the political and devising ways in which antagonism can be transformed into agonism - which is a way of transforming friend/enemy 
distinction into friend/adversary. As a result an opponent is no longer an enemy who poses an existential threat, but rather an adversary whose legitimacy as a political competitor should be acknowledged and respected Democratic adversaries, even in conflict, see themselves as belonging to the same political association and as sharing a commitment to the ethico-political values identified as a framework of liberal democracy (Mouffe, 2011, pp. 9-10). According to Mouffe, only such an approach can provide democratic channels for the expression of political conflicts and at the same time to supply the key that allows for differential treatment of global inequalities.

\section{Concluding Remarks}

One could challenge the distinction between the politics of faith (perfection) and the politics of scepticism (imperfection) arguing that presented approaches are both optimistic (faith) and pessimistic (scepticism). This is quite a bit of truth. Giddens and Beck express a great faith in man, in the possibility of finding consensus, in reason, in dialogue and so on. Mouffe is on these issues rather pessimistic. However, it should be noted that, while remaining compatible with Oakeshott's approach, the only criterion of dividing between these two models of politics is the power of government.

From this point of view, as far as liberal thought adheres to individualism and rationalism, it moves away from the traditionally understood politics and moves the political to the sphere of economy or ethics. Consequently, the institution of government should be interpreted not as means for arriving at the "truth" or excluding "error", but only as means for choosing decisions of some sort to be made (Oakeshott, 1996, p. 27). In this sense political power has become exhausted, thus the post-political Zeitgeist is undoubtedly the politics of human imperfection. At the same time Mouffe's approach, which stands up for a strong government, moreover, is not afraid of conflict, struggles and radical changes, deserves to be called politics of human perfection.

This article presents only a narrow aspect of the debate between Mouffe, Giddens and Back. The issues of various forms of inequalities and ways to eliminate them (otherwise important) have been omitted or merely sketched. The basic framework of my argument is theoretical: I have been focused on sources and assumptions determining presented theories, which in turn involves an analysis of the concept of the political and the basic rules that specify the functioning of democracy.

\section{References}

Bauman, Z. (2008). Wspólnota. Kraków: Wydawnictwo Literackie.

Beck, U. (1997). The reinvention of politics: Rethinking modernity in the global social order. Cambridge: Polity Press.

Beck, U. (2007). Beyond class and nation: Reframing social inequalities in a globalizing world. The British Journal of Sociology, $58(4), 679-705$.

Beck, U., \& Giddens, A., \& Lash, S. (2009). Modernizacja refleksyjna. Warszawa: PWN.

Beck, U. \& Grande, E. (2009). Europa kosmopolityczna. Warszawa: Wydawnictwo Naukowe Scholar.

Dybel, P. \& Wróbel, S. (2008). Granice polityczności. Warszawa: Aletheia.

Giddens, A. (1991). Modernity and self identity. Cambridge: Polity.

Giddens, A. (1994). Beyond left and right. Cambridge: Polity.

Giddens, A. (February 12, 1999). Better than warmed-over porridge. New Statesman, 25-26.

Giddens, A. (2000). The third way and its critics. Cambridge: Polity.

Kiely, R. (2005). The clash of globalizations: Neo-liberalism, the third way and anti-globalization. Leiden-Boston: Brill.

Martell, L. (2008, June). Back's cosmopolitan politics. Contemporary Politics, 14(2), 129-143. 
Martell, L. (2016, July 4). Global inequality, human rights and power: A critique of Ulrich Beck's cosmopolitanism. Retrieved from users.sussex.ac.uk/ ssfa2/inequalityrightspower.htm

Mouffe, C. (2005). On the political. London-New York: Routledge.

Mouffe, C. (Ed.). (2011). Wyzwanie Schmitta, in Carl Schmitt. Wyzwanie polityczności. Warszawa: Wydawnictwo Krytyki Politycznej.

Oakeshott, M. (1996). The politics of faith \& the politics of scepticism. New Haven-London: Yale University Press.

Rawls, J. (1998). Liberalizm polityczny. Warszawa: PWN.

Rencière, J. (1991). Disagreement. Minneapolis: University of Minnesota Press. 